\title{
Synthesis and Characterization of the Novel Copper(I) Anion $\left[\mathrm{Cu}\left(\mathrm{PPh}_{3}\right) \mathrm{Br}_{2}\right]^{-} \dagger$
}

\author{
Graham A. Bowmaker* \\ Department of Chemistry, University of Auckland, Private Bag, Auckland, New Zealand \\ Brian W. Skelton and Allan H. White \\ Department of Physical and Inorganic Chemistry, University of Western Australia, Nedlands, Western \\ Australia 6009, Australia \\ Peter C. Healy \\ Department of Science and Technology, Griffith University, Nathan, Queensland 4111, Australia
}

Solid-state ${ }^{31} \mathrm{P}$ n.m.r., far-i.r. spectroscopy and single-crystal $X$-ray diffraction techniques have been used to characterize a new type of ionic copper(1) compound: $\left[\mathrm{PPh}_{3} \mathrm{Me}\right]\left[\mathrm{Cu}\left(\mathrm{PPh}_{3}\right) \mathrm{Br}_{2}\right]$. $X$-Ray analysis shows the $\mathrm{PPh}_{3}$ ligand to be co-ordinated to the copper atom of the $\mathrm{CuBr}_{2}$ unit in a trigonal planar arrangement, with $\mathrm{Cu}-\mathrm{P} 2.210(3), \mathrm{Cu}-\mathrm{Br} 2.367(2), 2.386(2) \AA$ and $\mathrm{Br}-\mathrm{Cu}-\mathrm{Br}$ $114.9(1)^{\circ}$ \{monoclinic, space group $P n, a=11.779(5), b=9.914(5), c=14.705(10) \AA$, $\beta=94.92(5)^{\circ}, Z=2, R=0.037$ for 1570 'observed' $[I>3 \sigma(/)]$ reflections $\}$. The far-i.r. spectrum shows a strong band at $195 \mathrm{~cm}^{-1}$ assigned to the antisymmetric $\mathrm{Cu}-\mathrm{Br}$ stretching mode of the $\mathrm{CuBr}_{2}$ unit, and a weaker band at $150 \mathrm{~cm}^{-1}$ assigned to the symmetric $\mathrm{Cu}-\mathrm{Br}$ stretching mode. This assignment is supported by an approximate normal-co-ordinate analysis, and the resulting $\mathrm{Cu}-\mathrm{Br}$ force constant is compared with values obtained in similar analyses of related bromocopper( 1 ) complexes. The cross-polarization magic angle spinning ${ }^{31} \mathrm{P}$ n.m.r. spectrum shows a strong signal at 21 p.p.m. (relative to $85 \% \mathrm{H}_{3} \mathrm{PO}_{4}$ ) due to the cation, and a weaker quartet centred at -14 p.p.m. due to the co-ordinated $\mathrm{PPh}_{3}$ in the anion, with line spacings due to $\mathrm{Cu}-\mathrm{P}$ coupling of $1.37,1.69$, and $1.92 \mathrm{kHz}$.

Copper(I) generally shows a preference for a co-ordination number of four in its complexes, although an increasing number of complexes have been reported in which it has co-ordination numbers of two or three. ${ }^{1}$ The factors which determine the preferred co-ordination number are not entirely clear, however, and further data relevant to this question should be obtainable by studying related series of complexes to determine the range of possible co-ordination numbers in the series, and by measuring physical properties of the complexes which yield information about the changes in bond strength and valence-electron distribution which occur with change in co-ordination number. Thus, for the series $\mathrm{CuX}_{n}{ }^{(n-1)-}$ with $\mathrm{X}=\mathrm{Br}$ or I, complexes up to $n=3$ are known, whereas for $\mathrm{X}=\mathrm{Cl}$ only up to $n=2$. The metal-halogen force constants obtained from the $v(\mathrm{Cu}-\mathrm{X})$ vibrational frequencies for the $\mathrm{X}=\mathrm{Br}$ or I complexes decrease rapidly with $n$, and these results suggest that the $n=4$ complexes should not exist for this series. ${ }^{2}$ In the case of the series $\mathrm{Cu}\left(\mathrm{PPh}_{3}\right)_{n} \mathrm{X}$, mononuclear complexes with $n=2$ or 3 are known for $\mathrm{X}=\mathrm{Cl}, \mathrm{Br}$, or I. ${ }^{3.4}$ Thus, the replacement of a halide ligand $\mathrm{X}^{-}$by $\mathrm{PPh}_{3}$ appears to favour higher co-ordination numbers in copper(I) complexes.

In a development of these studies, we are examining the ability of neutral ligands to co-ordinate to the two-co-ordinate anions $\mathrm{CuX}_{2}(\mathrm{X}=\mathrm{Cl}, \mathrm{Br}$, or $\mathrm{I})$. In the present communication we report the preparation and characterization by $X$-ray diffraction, i.r., and solid-state cross-polarization magic angle spinning (c.p.m.a.s.) n.m.r. spectroscopy of the novel anion $\left[\mathrm{Cu}\left(\mathrm{PPh}_{3}\right) \mathrm{Br}_{2}\right]$ in the compound $\left[\mathrm{PPh}_{3} \mathrm{Me}\right]\left[\mathrm{Cu}\left(\mathrm{PPh}_{3}\right) \mathrm{Br}_{2}\right]$.

\section{Experimental \\ Preparation of Compounds--Methyltriphenylphosphonium dibromo(triphenylphosphine)cuprate( 1$), \quad\left[\mathrm{PPh}_{3} \mathrm{Me}\right]\left[\mathrm{Cu}\left(\mathrm{PPh}_{3}\right)\right.$ -}

† Supplementary data available: see Instructions for Authors, J. Chem. Soc.. Dalton Trans.. 1988, Issue 1. pp. xvii-xx.
$\mathrm{Br}_{2}$ ]. Copper(I) bromide $(0.36 \mathrm{~g}, 2.5 \mathrm{mmol})$, triphenylphosphine $(0.66 \mathrm{~g}, 2.5 \mathrm{mmol})$, and methyltriphenylphosphonium bromide $(0.89 \mathrm{~g}, 2.5 \mathrm{mmol})$ were added to dichloromethane $\left(15 \mathrm{~cm}^{3}\right)$ and the mixture was stirred until all the solid material had dissolved. The solution was heated on a water-bath until it boiled, and then diethyl ether was slowly added until the first permanent precipitate formed. On cooling to room temperature the solution deposited white crystals which were collected by filtration and dried in a vacuum, m.p. $167-168.5^{\circ} \mathrm{C}$ (Found: C, 58.1; $\mathrm{H}, 4.9$. Calc. for $\mathrm{C}_{37} \mathrm{H}_{33} \mathrm{Br}_{2} \mathrm{CuP}_{2}$ : C, 58.3; $\mathrm{H}, 4.4 \%$ ).

The unsolvated adducts of $\left[\left(\mathrm{Ph}_{3} \mathrm{P}\right) \mathrm{CuBr}{ }_{2} \mathrm{Cu}\left(\mathrm{PPh}_{3}\right)_{2}\right]$ and the 'step' isomer of $\left[\mathrm{Cu}\left(\mathrm{PPh}_{3}\right) \mathrm{Br}\right]_{4}$ were prepared as previously described. ${ }^{5}$

Structure Determination.-Crystal data. $\mathrm{C}_{37} \mathrm{H}_{33} \mathrm{Br}_{2} \mathrm{CuP}_{2}$, $M=763.0$, monoclinic, space group $P n\left[C_{s}^{2}\right.$, no. 7 (variant) , $a=11.779(5), b=9.914(5), c=14.705(10) \AA, \beta=94.92(5)^{\circ}$, $U=1711(2) \AA^{3}, D_{\mathrm{c}}(Z=2)=1.48 \mathrm{~g} \mathrm{~cm}^{-3}, \quad F(000)=768$, $\mu\left(\right.$ Mo- $\left.K_{\alpha}\right)=30.3 \mathrm{~cm}^{-1}$, specimen $0.51 \times 0.40 \times 0.04 \mathrm{~mm}$ (capillary), $A^{*}{ }_{\text {min.,max. }}=1.13,2.50$ (Gaussian correction).

A unique data set was measured to $2 \theta_{\max }=50^{\circ}$ on a Syntex $P 2_{1}$ four-circle diffractometer (monochromatic Mo- $K_{x}$ radiation source, $\lambda=0.71069 \AA$ ) in conventional $2 \theta-\theta$ scan mode at 295 K. 2243 Independent reflections were measured, 1570 with $I>3 \sigma(I)$ being considered 'observed' and used in the fullmatrix least-squares refinement after solution of the structure by vector methods. $\left(x, y, z, U_{\text {iso }}\right)_{\mathrm{H}}$ were included at estimated values. Residuals on $|F|$ at convergence were $R=0.037, R^{\prime}=0.024$ (preferred hand); statistical reflection weights were used, derived from $\sigma^{2}(I)=\sigma^{2}(I)_{\text {diff }}+0.0001 \sigma^{4}(I)_{\text {diff. }}$. The structure refined smoothly in the chosen space group with no anomalies with respect to features such as thermal envelopes or disorder. The residuals were lowest for the chosen enantiomer. Neutral atom complex scattering factors were used. ${ }^{6}$ No significant extinction effects were observed. Computation used the XTAL83 program system $^{7}$ implemented by S. R. Hall on a Perkin-Elmer 3240 
Table 1. Non-hydrogen atom co-ordinates for $\left[\mathrm{Cu}\left(\mathrm{PPh}_{3}\right) \mathrm{Br}_{2}\right]^{-}$

\begin{tabular}{|c|c|c|c|c|c|c|}
\hline \multirow[b]{2}{*}{ Atom } & \multicolumn{3}{|c|}{$l=1$} & \multicolumn{3}{|c|}{$l=2$} \\
\hline & $x$ & $y$ & $z$ & $x$ & $y$ & $z$ \\
\hline $\mathrm{Cu}(1)^{*}$ & 0 & $0.2643(1)$ & 0 & - & - & - \\
\hline $\operatorname{Br}(1)$ & $0.1737(1)$ & $0.1447(1)$ & $0.0365(1)$ & - & - & - \\
\hline $\operatorname{Br}(2)$ & $-0.1588(1)$ & $0.1801(1)$ & $0.0705(1)$ & - & - & - \\
\hline $\mathbf{P}(l)$ & $-0.0221(2)$ & $0.4491(3)$ & $-0.0838(3)$ & $0.4545(2)$ & $0.7834(3)$ & $0.0170(2)$ \\
\hline $\mathrm{C}(l 11)$ & $0.0966(8)$ & $0.5000(10)$ & $-0.1486(6)$ & $0.4908(7)$ & $0.8594(10)$ & $0.1267(6)$ \\
\hline $\mathrm{C}(l 12)$ & $0.2051(8)$ & $0.4509(10)$ & $-0.1191(7)$ & $0.4436(9)$ & $0.9827(11)$ & $0.1465(7)$ \\
\hline $\mathrm{C}(l 13)$ & $0.2965(8)$ & $0.4876(11)$ & $-0.1644(6)$ & $0.4739(10)$ & $1.0452(12)$ & $0.2287(8)$ \\
\hline$C(l 14)$ & $0.2866(8)$ & $0.5740(11)$ & $-0.2358(7)$ & $0.5527(10)$ & $0.9832(13)$ & $0.2906(7)$ \\
\hline $\mathrm{C}(l 15)$ & $0.1806(9)$ & $0.6251(12)$ & $-0.2666(7)$ & $0.6003(9)$ & $0.8591(11)$ & $0.2719(7)$ \\
\hline$C(l 16)$ & $0.0868(9)$ & $0.5870(11)$ & $-0.2206(7)$ & $0.5672(8)$ & $0.7986(11)$ & $0.1891(7)$ \\
\hline $\mathrm{C}(121)$ & $-0.0484(8)$ & $0.5944(9)$ & $-0.0126(7)$ & $0.4869(8)$ & $0.6054(9)$ & $0.0216(6)$ \\
\hline $\mathrm{C}(122)$ & $-0.1207(8)$ & $0.5789(10)$ & $0.0553(7)$ & $0.4163(9)$ & $0.5172(11)$ & $0.0620(7)$ \\
\hline $\mathrm{C}(123)$ & $-0.1427(8)$ & $0.6846(10)$ & $0.1122(7)$ & $0.4352(8)$ & $0.3803(11)$ & $0.0607(7)$ \\
\hline $\mathrm{C}(l 24)$ & $-0.0928(9)$ & $0.8068(10)$ & $0.1025(7)$ & $0.5255(9)$ & $0.3318(10)$ & $0.0156(6)$ \\
\hline $\mathrm{C}(125)$ & $-0.0210(9)$ & $0.8272(10)$ & $0.0376(8)$ & $0.5962(8)$ & $0.4199(11)$ & $-0.0239(7)$ \\
\hline $\mathrm{C}(126)$ & $0.0024(9)$ & $0.7231(10)$ & $-0.0217(7)$ & $0.5776(8)$ & $0.5545(11)$ & $-0.0248(7)$ \\
\hline $\mathrm{C}(l 31)$ & $-0.1482(7)$ & $0.4480(10)$ & $-0.1678(6)$ & $0.5322(8)$ & $0.8616(11)$ & $-0.0701(6)$ \\
\hline $\mathrm{C}(132)$ & $-0.1871(8)$ & $0.3286(10)$ & $-0.2013(6)$ & $0.4890(9)$ & $0.8544(11)$ & $-0.1599(7)$ \\
\hline $\mathrm{C}(133)$ & $-0.2794(8)$ & $0.3219(12)$ & $-0.2630(7)$ & $0.5549(10)$ & $0.9034(13)$ & $-0.2254(7)$ \\
\hline $\mathrm{C}(134)$ & $-0.3355(8)$ & $0.4393(13)$ & $-0.2936(7)$ & $0.6599(11)$ & $0.9534(12)$ & $-0.2015(8)$ \\
\hline $\mathrm{C}(135)$ & $-0.2977(8)$ & $0.5613(11)$ & $-0.2609(7)$ & $0.7030(9)$ & $0.9665(13)$ & $-0.1130(8)$ \\
\hline$C(136)$ & $-0.2033(8)$ & $0.5673(10)$ & $-0.1979(9)$ & $0.6370(10)$ & $0.9188(12)$ & $-0.0462(7)$ \\
\hline C & - & - & - & $0.3048(8)$ & $0.8011(11)$ & $-0.0144(7)$ \\
\hline
\end{tabular}

* Defines origin.

computer and the CHEM-X program package (Chemical Designs Ltd.) implemented on a VAX-780 computer. Nonhydrogen atom co-ordinates are listed in Table $1 ; \mathrm{P}(1)$ refers to the phosphorus atom in the anion and $\mathrm{P}(2)$ to the phosphorus atom in the cation. The un-numbered $C$ is the methyl carbon in the $\left[\mathrm{PPh}_{3} \mathrm{Me}\right]^{+}$cation. The atom labelling scheme adopted for each $\mathrm{PPh}_{3}$ moiety is such that the ortho carbon atoms $\mathrm{C}(\mathrm{m} 2)$, where $m$ is the ring number, are defined as those atoms above the $\mathrm{PC}_{3}$ pyramid of the ligand.

Additional material available from the Cambridge Crystallographic Data Centre comprises H-atom co-ordinates, thermal parameters, and remaining bond distances and angles.

Spectroscopy.-Solid-state c.p.m.a.s. ${ }^{31} \mathrm{P}$ n.m.r. spectra were obtained at room temperature on a Bruker CXP-300 spectrometer at $121.47 \mathrm{MHz}$ using ${ }^{1} \mathrm{H}-{ }^{31} \mathrm{P}$ cross polarization with radiofrequency fields of 8 and $20 \mathrm{G}\left(\mathrm{G}=10^{-4} \mathrm{~T}\right)$ respectively.

Far-i.r. spectra were recorded at $c a .298 \mathrm{~K}$ as petroleum jelly mulls between Polythene plates on a Digilab FTS-60 Fouriertransform i.r. spectrometer employing a FTS-60V vacuum optical bench and a $6.25-\mu \mathrm{m}$ mylar beam splitter.

\section{Results and Discussion}

Copper(I) bromide, bromide ion, and triphenylphosphine combine in a 1:1:1 ratio to form the $\left[\mathrm{Cu}\left(\mathrm{PPh}_{3}\right) \mathrm{Br}_{2}\right]^{-}$ion which was crystallized from dichloromethane-diethyl ether as its $\left[\mathrm{PPh}_{3} \mathrm{Me}\right]^{+}$salt. Attempts to prepare the 2:1 complex of $\mathrm{PPh}_{3}$ with $\mathrm{CuBr}_{2}{ }^{-}$by using an excess of $\mathrm{PPh}_{3}$ resulted only in the formation of the $1: 1$ complex.

$\mathrm{X}$-Ray Structure Determination.-The structure of the $\left[\mathrm{Cu}\left(\mathrm{PPh}_{3}\right) \mathrm{Br}_{2}\right]^{-}$anion is shown in Figure 1. The $\mathrm{PPh}_{3}$ ligand is co-ordinated to the copper atom of the $\mathrm{CuBr}_{2}$ unit in a threeco-ordinate trigonal-planar arrangement, with $\mathrm{Cu}-\mathrm{P} 2.210(3)$, $\mathrm{Cu}-\mathrm{Br}$ 2.367(2), 2.386(2) $\AA$ and $\mathrm{Br}-\mathrm{Cu}-\mathrm{Br}$ 114.9(1), $\mathrm{P}-\mathrm{Cu}-\mathrm{Br}$

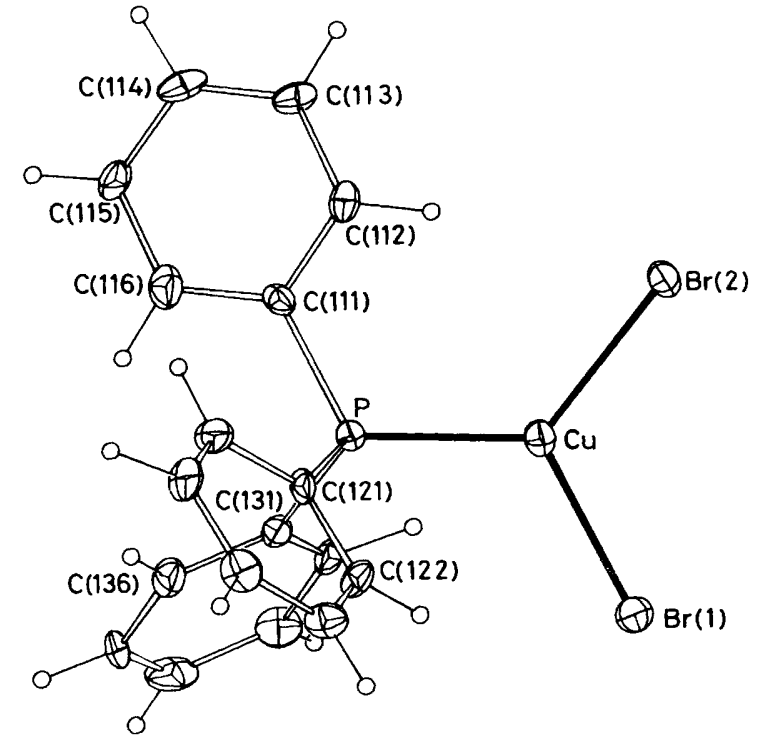

Figure 1. The anion, projected normal to the $\mathrm{PCuBr}_{2}$ plane; $20 \%$ thermal ellipsoids and atom numbering are given for the non-hydrogen atoms. Hydrogen atoms have an arbitrary radius of $0.1 \AA$

$118.5(1), 126.5(1)^{\circ}$. The $\mathrm{Cu}-\mathrm{P}$ distance is somewhat surprisingly similar to the distances of $2.191(2) \AA$ found for $\left[\left(\mathrm{Ph}_{3} \mathrm{P}\right)\right.$ $\left.\mathrm{CuBr}{ }_{2} \mathrm{Cu}\left(\mathrm{PPh}_{3}\right)_{2}\right]$ and 2.206(5) $\AA$ found in the 'step' isomer of $\left[\mathrm{Cu}\left(\mathrm{PPh}_{3}\right) \mathrm{Br}\right]_{4},{ }^{5}$ both of which contain the $\left(\mathrm{PPh}_{3}\right) \mathrm{CuBr}_{2}$ unit (Table 2). The $\mathrm{Cu}-\mathrm{Br}$ distances increase on co-ordination of the $\mathrm{PPh}_{3}$ molecule to $\mathrm{CuBr}{ }_{2}{ }^{-}$from an average value of $2.22 \AA$ found in compounds containing uncomplexed linear $\mathrm{CuBr}_{2}^{-}$ions ${ }^{8}$ to a mean value of $2.377 \AA$ in $\left[\mathrm{Cu}\left(\mathrm{PPh}_{3}\right) \mathrm{Br}_{2}\right]^{-}$, with the $\mathrm{Br}-\mathrm{Cu}-\mathrm{Br}$ angle decreasing from linearity to a value less than $120^{\circ}$. In the complex $\left[\mathrm{tst}^{\cdot+}\left[\mathrm{CuBr}_{2}\right]^{-}(\mathrm{tst}=\right.$ 'tetraselenotetracene', naph- 
Table 2. Core geometries for molecules containing the $\left(\mathrm{PPh}_{3}\right) \mathrm{CuBr}$ fragment

\begin{tabular}{lccc}
\multicolumn{1}{c}{ Parameter $^{a}$} & {$\left[\mathrm{Cu}\left(\mathrm{PPh}_{3}\right) \mathrm{Br}_{2}\right]^{-}$} & {$\left[\left(\mathrm{Ph}_{3} \mathrm{P}\right) \mathrm{CuBr}{ }_{2} \mathrm{Cu}\left(\mathrm{PPh}_{3}\right)_{2}\right]^{b}$} & {$\left[\mathrm{Cu}\left(\mathrm{PPh}_{3}\right) \mathrm{Br}\right]_{4}$ 'step' $^{\text {b }}$} \\
$\mathrm{Cu}-\mathrm{Br}(1)$ & $2.386(2)$ & $2.409(2)$ & $2.427(2)$ \\
$\mathrm{Cu}-\mathrm{Br}(2)$ & $2.367(2)$ & $2.364(2)$ & $2.371(3)$ \\
$\mathrm{Cu}-\mathrm{P}$ & $2.210(3)$ & $2.191(2)$ & $2.206(5)$ \\
$\mathrm{P}-\mathrm{Cu}-\mathrm{Br}(1)$ & $126.5(1)$ & $129.7(1)$ & $119.2(1)$ \\
$\mathrm{P}-\mathrm{Cu}-\mathrm{Br}(2)$ & $118.5(1)$ & $117.8(1)$ & $127.7(1)$ \\
$\mathrm{Br}(1)-\mathrm{Cu}-\mathrm{Br}(2)$ & $114.9(1)$ & $111.5(1)$ & $112.9(1)$
\end{tabular}

${ }^{a}$ Distances $(\AA)$, angles $\left({ }^{\circ}\right){ }^{b}$ Ref. 5 .

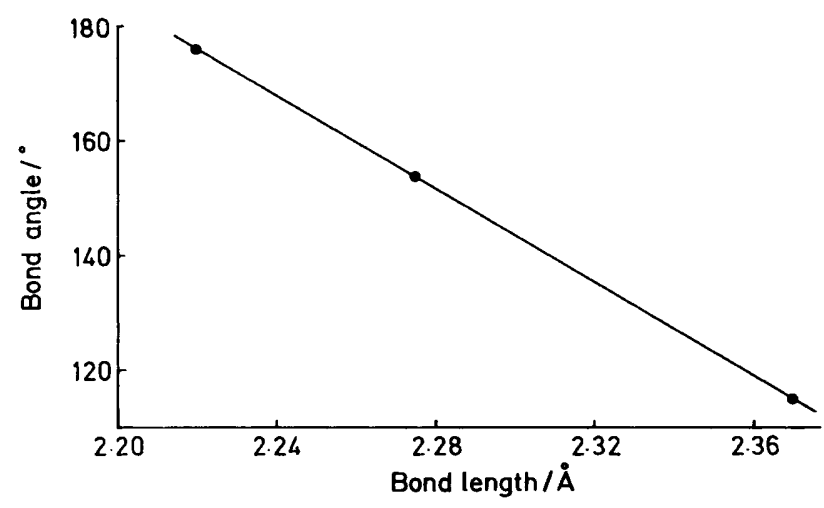

Figure 2. $\mathrm{Plot}$ of $\mathrm{Br}-\mathrm{Cu}-\mathrm{Br}$ angle vs. $\mathrm{Cu}-\mathrm{Br}$ distance in compounds containing a $\mathrm{CuBr}_{2}$ unit<smiles>PC(P)P</smiles>

(1)<smiles>FC(P)Br</smiles>

(II)<smiles>PC(Br)Br</smiles>

(III)<smiles>BrC(Br)Br</smiles>

(IV)
Scheme.

thaceno[5,6-cd:11,12- $\left.c^{\prime} d^{\prime}\right]$ bis[1,2]diselenole), ${ }^{9}$ a weak $\mathrm{Cu}$ $\cdots \mathrm{Br}$ bridging interaction between the $\mathrm{CuBr}_{2}$ units results in a decrease of the $\mathrm{Br}-\mathrm{Cu}-\mathrm{Br}$ angle to $153.8(1)^{\circ}$, and intermediate $\mathrm{Cu}-\mathrm{Br}$ distances of $2.267(2)$ and $2.282(3) \AA$ (Figure 2). The $\mathrm{Cu}-\mathrm{Br}$ distances and $\mathrm{Br}-\mathrm{Cu}-\mathrm{Br}$ angles in the trigonal $\left(\mathrm{PPh}_{3}\right) \mathrm{CuBr}_{2}$ fragment of the aggregated multinuclear complex $\left[\left(\mathrm{Ph}_{3} \mathrm{P}\right) \mathrm{CuBr}{ }_{2} \mathrm{Cu}\left(\mathrm{PPh}_{3}\right)_{2}\right]$ and the 'step' isomer of $\left[\mathrm{Cu}\left(\mathrm{PPh}_{3}\right) \mathrm{Br}\right]_{4}$ are also quite similar to those in the present compound (Table 2). Consideration of the data for the bridged complexes alone might have led to the conclusion that the reduction of the $\mathrm{Br}-\mathrm{Cu}-\mathrm{Br}$ angle to less than $120^{\circ}$ is dictated by the bonding requirements of the bridging bromine atoms. It is significant to note, therefore, that this also occurs in $\left[\mathrm{Cu}\left(\mathrm{PPh}_{3}\right) \mathrm{Br}_{2}\right]^{-}$, where no such bridging bonds occur.

Structurally, the present compound is a member of the series $\left[\mathrm{Cu}\left(\mathrm{PPh}_{3}\right)_{n} \mathrm{Br}_{3-n}\right]^{(2-n)-}(\mathrm{I})-(\mathrm{IV})$. In a range of structures containing the $\left[\mathrm{Cu}\left(\mathrm{PPh}_{3}\right)_{3}\right]^{+}$cation $(\mathrm{I}),{ }^{10}$ the counter anion is co-ordinated to the copper atom and the $\mathrm{P}_{3} \mathrm{Cu}$ core deviates significantly from planarity. For complexes with weakly coordinating anions such as $\mathrm{ClO}_{4}{ }^{-}$or $\mathrm{BF}_{4}{ }^{-}$the average $\mathrm{P}-\mathrm{Cu}-\mathrm{P}$ angle is $116^{\circ}$ and $\mathrm{Cu}-\mathrm{P} 2.31 \AA$. For the neutral planar compound $\left[\mathrm{Cu}\left(\mathrm{PPh}_{3}\right)_{2} \mathrm{Br}\right]$, (II), the $\mathrm{Cu}-\mathrm{P}$ distances decrease to an average value of $2.27 \AA$ and $\mathrm{Cu}-\mathrm{Br} 2.346(2) \AA .{ }^{3}$ In the present compound (III), as already discussed, Cu-P 2.210(3) $\AA$ and the average $\mathrm{Cu}-\mathrm{Br}$ distance is $2.37 \AA$. Structural data are, as yet, not available for the $\left[\mathrm{CuBr}_{3}\right]^{2-}$ anion, (IV). ${ }^{2}$ These results are

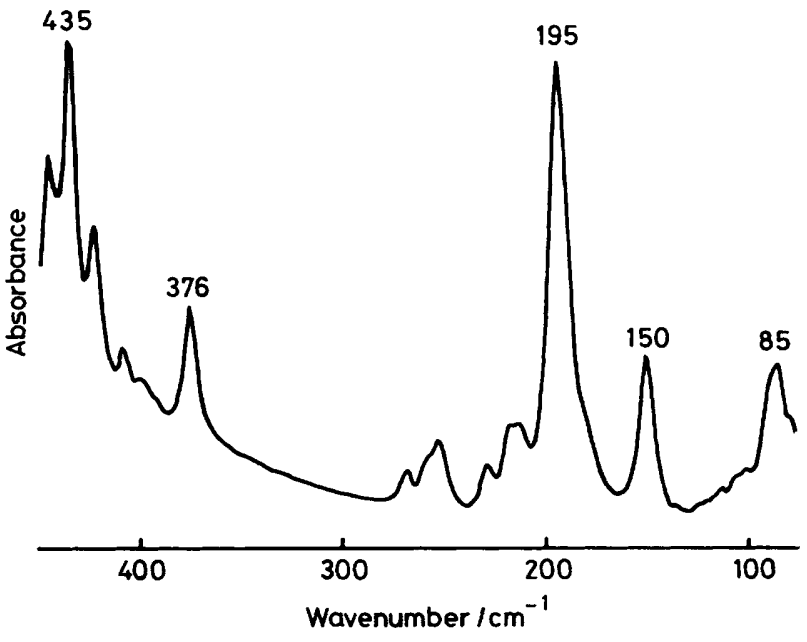

Figure 3. Far-i.r. spectrum of $\left[\mathrm{PPh}_{3} \mathrm{Me}\right]\left[\mathrm{Cu}\left(\mathrm{PPh}_{3}\right) \mathrm{Br}_{2}\right]$

consistent with a greater $\sigma$-donor capacity for the $\mathrm{PPh}_{3}$ ligand relative to the $\mathrm{Br}^{-}$anion, leading to strong $\mathrm{Cu}-\mathrm{P}$ bonds in which the $\mathrm{Cu}-\mathrm{P}$ distance is determined primarily by the packing requirements of one, two, or three $\mathrm{PPh}_{3}$ ligands around the relatively small $\mathrm{Cu}^{+}$ion. It is possible to argue from these results that the $\mathrm{Cu}-\mathrm{Br}$ bond is relatively ionic, and in this context the similarity in the $\mathrm{PCuBr}_{2}$ core geometries of $\left[\mathrm{Cu}\left(\mathrm{PPh}_{3}\right) \mathrm{Br}_{2}\right]^{-},\left[\left(\mathrm{Ph}_{3} \mathrm{P}\right) \mathrm{CuBr}{ }_{2} \mathrm{Cu}\left(\mathrm{PPh}_{3}\right)_{2}\right]$, and the 'step' isomer of $\left[\mathrm{Cu}\left(\mathrm{PPh}_{3}\right) \mathrm{Br}\right]_{4}$ is an important result.

Far-i.r. Spectrum.--The far i.r. spectrum of $\left[\mathrm{PPh}_{3} \mathrm{Me}\right]-$ $\left[\mathrm{Cu}\left(\mathrm{PPh}_{3}\right) \mathrm{Br}_{2}\right]$ is shown in Figure 3. By comparison with the spectrum of $\left[\mathrm{PPh}_{3} \mathrm{Me}\right] \mathrm{Br}$, the band at $376 \mathrm{~cm}^{-1}$ can be assigned to the cation and the bands at 195 and $150 \mathrm{~cm}^{-1}$ to the $\left[\mathrm{Cu}\left(\mathrm{PPh}_{3}\right) \mathrm{Br}_{2}\right]^{-}$complex. By analogy with the results for other triphenylphosphine bromocopper(I) complexes, ${ }^{11}$ the strongest bands in the far-i.r. are expected to be the $\mathrm{Cu}-\mathrm{Br}$ stretching modes, $v(\mathrm{CuBr})$. Thus the two bands at 195 and $150 \mathrm{~cm}^{-1}$ are assigned to the two expected $v(\mathrm{CuBr})$ modes of the $\mathrm{CuBr}_{2}$ unit. We have found previously that the metal-halogen vibrational frequencies of the metal-halogen core in phosphine metal halide complexes can be calculated by carrying out a normal-coordinate analysis on the metal-halogen core only. ${ }^{12}$ We have used this approach here to calculate the frequencies of a $\mathrm{CuBr}_{2}$ unit with two equivalent bonds and $\mathrm{a} \mathrm{Br}-\mathrm{Cu}-\mathrm{Br}$ bond angle of $115^{\circ}$. A simple diagonal force field was used. This involves a $\mathrm{Cu}-\mathrm{Br}$ bond stretching force constant $f_{r}$ and a $\mathrm{Br}-\mathrm{Cu}-\mathrm{Br}$ anglebending force constant $f_{\alpha}$. With the assumption $f_{\alpha}=0.1 f_{\mathrm{r}}$ which we have used in this type of calculation previously, $f_{\mathrm{r}}$ was varied and the vibrational frequencies calculated to give the best fit between the observed and experimental frequencies. The results are shown in Table 3. The agreement between the observed and 
Table 3. Observed and calculated $v(\mathrm{CuBr})$ wavenumbers, and $\mathrm{Cu}-\mathrm{Br}$ bond-stretching force constants for some bromocopper(I) complexes

\begin{tabular}{|c|c|c|c|c|}
\hline \multirow[b]{2}{*}{ Complex } & \multicolumn{2}{|c|}{$v / \mathrm{cm}^{-1}$} & \multirow[b]{2}{*}{$f_{\mathrm{r}} / \mathrm{N} \mathrm{m}^{-1}$} & \multirow[b]{2}{*}{ Ref } \\
\hline & obs. & calc. & & \\
\hline$\left[\mathrm{CuBr}_{2}\right]^{-}$ & 321 & $321\left(\Sigma_{u}^{+}\right)$ & 157 & 13 \\
\hline & 191 & $191\left(\Sigma_{g}^{+}\right)$ & & \\
\hline$\left[\mathrm{Cu}\left(\mathrm{PPh}_{3}\right)_{2} \mathrm{Br}_{2}\right]^{-}$ & 195 & $189\left(B_{1}\right)$ & 60 & * \\
\hline & 150 & $156\left(A_{1}\right)$ & & \\
\hline$\left[\mathrm{Cu}\left(\mathrm{PPh}_{3}\right)_{2} \mathrm{Br}\right]$ & 221 & $221\left(A_{1}\right)$ & 102 & $11, *$ \\
\hline$\left[\left(\mathrm{Ph}_{3} \mathrm{P}\right) \mathrm{CuBr}_{2} \mathrm{Cu}\left(\mathrm{PPh}_{3}\right)_{2}\right]$ & 180 & $\begin{array}{l}180\left(B_{1}\right), \\
153\left(A_{1}\right) \\
129\left(B_{1}\right), \\
127\left(A_{1}\right)\end{array}$ & $\begin{array}{c}55 \\
\text { (trigonal } \mathrm{Cu} \text { ) } \\
32 \\
\text { (tetrahedral } \mathrm{Cu} \text { ) }\end{array}$ & $14, *$ \\
\hline$\left[\mathrm{Cu}\left(\mathrm{PPh}_{3}\right) \mathrm{Br}\right]_{4}$ 'step' & $\begin{array}{l}174 \\
135\end{array}$ & & & 12 \\
\hline$\left[\mathrm{Cu}\left(\mathrm{PPh}_{3}\right) \mathrm{Br}\right]_{4}$ 'cubane' & $\begin{array}{l}144 \\
119\end{array}$ & $\begin{array}{l}145\left(T_{2}\right) \\
123\left(T_{2}\right)\end{array}$ & 33 & 12 \\
\hline * This work. & & & & \\
\hline
\end{tabular}

calculated frequencies is sufficiently good to support the above assignment, and shows that the higher-frequency band is due to the antisymmetric stretch ( $B_{1}$ symmetry) and the lowerfrequency band to the symmetric stretch ( $A_{1}$ symmetry).

As expected from the comparison of bond lengths discussed above, the $\mathrm{CuBr}$ force constant in $\left[\mathrm{Cu}\left(\mathrm{PPh}_{3}\right) \mathrm{Br}_{2}\right]^{-}$is significantly lower than the value found for $\mathrm{CuBr}_{2}-{ }^{-13}$ This result parallels that found previously for $\left[\mathrm{M}\left(\mathrm{PPh}_{3}\right)_{n} \mathrm{X}\right](\mathrm{M}=\mathrm{Cu}, \mathrm{Ag}$, or $\mathrm{Au} ; \mathrm{X}=\mathrm{Cl}, \mathrm{Br}$, or I) where the $v(\mathrm{MX})$ frequency and the MX force constant are found to be strongly dependent on co-ordination number and MX bond length. ${ }^{3,11}$

Table 3 contains other data for comparison with the above results. Thus, the force constant $f_{\mathrm{r}}$ for the terminal $\mathrm{CuBr}$ bond in $\left[\mathrm{Cu}\left(\mathrm{PPh}_{3}\right)_{2} \mathrm{Br}\right]$ is significantly greater than that for the corresponding bonds in $\left[\mathrm{Cu}\left(\mathrm{PPh}_{3}\right)_{2} \mathrm{Br}_{2}\right]^{-}$. This is in agreement with the trends in the $\mathrm{CuBr}$ bond lengths in these complexes, as discussed above. A similar normal-co-ordinate calculation was carried out on the $\mathrm{Cu}_{2} \mathrm{Br}_{2}$ core of $\left[\left(\mathrm{Ph}_{3} \mathrm{P}\right) \mathrm{CuBr}{ }_{2} \mathrm{Cu}\left(\mathrm{PPh}_{3}\right)_{2}\right]$. This analysis shows that the i.r. bands at 180 and $128 \mathrm{~cm}^{-1}$ can be satisfactorily accounted for only if the force constant for the $\mathrm{Cu}-\mathrm{Br}$ bonds involving the trigonally co-ordinated copper atom is significantly greater than that involving the tetrahedrally co-ordinated copper atoms. From the results in Table 3 it can be seen that the force constant for the trigonal $\mathrm{Cu}-\mathrm{Br}$ bonds in this complex is only slightly smaller than that for the corresponding bonds in $\left[\mathrm{Cu}\left(\mathrm{PPh}_{3}\right) \mathrm{Br}_{2}\right]^{-}$. Again, this is in good agreement with observations made above concerning the relative bond lengths in these species. Likewise, the force constant for the $\mathrm{Cu}-\mathrm{Br}$ bonds involving the tetrahedral copper atom in $\left[\left(\mathrm{Ph}_{3} \mathrm{P}\right) \mathrm{CuBr}{ }_{2} \mathrm{Cu}\left(\mathrm{PPh}_{3}\right)_{2}\right]$ is almost identical to that for the $\mathrm{CuBr}$ bonds in $\left[\mathrm{Cu}\left(\mathrm{PPh}_{3}\right) \mathrm{Br}\right]_{4}$, which also involves tetrahedrally co-ordinated copper(I). Analysis of the potentialenergy distribution for the four calculated $v(\mathrm{CuBr})$ modes of $\left[\left(\mathrm{Ph}_{3} \mathrm{P}\right) \mathrm{CuBr}{ }_{2} \mathrm{Cu}\left(\mathrm{PPh}_{3}\right)_{2}\right]$ shows that the two higher-frequency modes are associated mainly with stretching of the $\mathrm{CuBr}$ bonds on the trigonal copper atom, while the two lower-frequency modes are associated with the tetrahedral copper atom. This result suggests an alternative explanation for the presence of two main bands in the far-i.r. spectrum of the 'step' $\left[\mathrm{Cu}\left(\mathrm{PPh}_{3}\right) \mathrm{Br}\right]_{4}($ Table 3$)$. This is that these two bands are due to the presence of trigonally and tetrahedrally co-ordinated copper atoms in the structure, rather than to the presence of doubly and triply bridging bromine atoms as postulated previously. ${ }^{12,14}$ These two descriptions are obviously related, but are not equivalent, as evidenced by the fact that $\left[\left(\mathrm{Ph}_{3} \mathrm{P}\right) \mathrm{CuBr}{ }_{2} \mathrm{Cu}\left(\mathrm{PPh}_{3}\right)_{2}\right]$ shows two well separated $v(\mathrm{CuBr})$

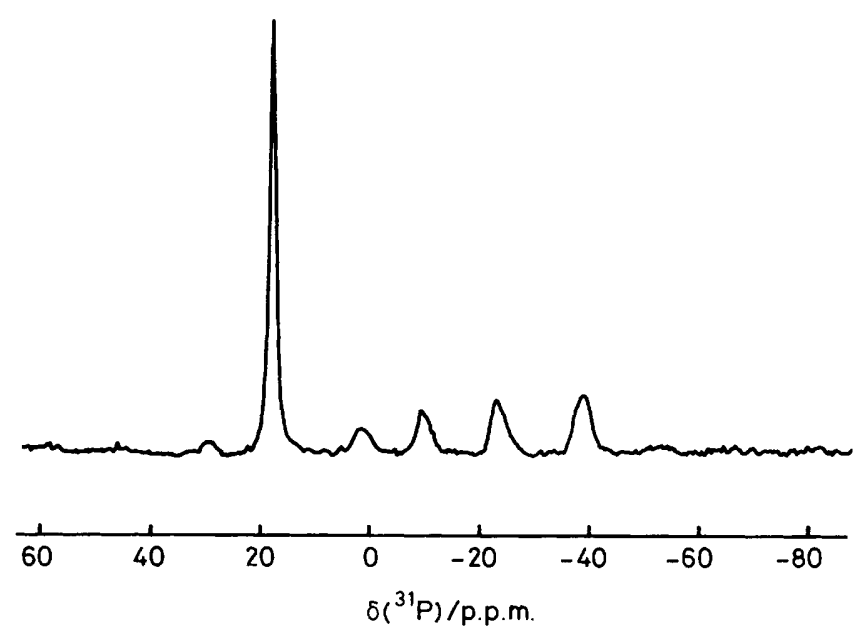

Figure 4. Phosphorus-31 c.p.m.a.s. n.m.r. spectrum of $\left[\mathrm{PPh}_{3} \mathrm{Me}\right]-$ $\left[\mathrm{Cu}\left(\mathrm{PPh}_{3}\right) \mathrm{Br}_{2}\right]$

bands, despite the presence of only doubly bridging bromine atoms in the structure.

Solid-state ${ }^{31} \mathrm{P}$ N.M.R. Spectrum.-The solid-state c.p.m.a.s. ${ }^{31} \mathrm{P}$ n.m.r. spectrum of $\left[\mathrm{PPh}_{3} \mathrm{Me}\right]\left[\mathrm{Cu}\left(\mathrm{PPh}_{3}\right) \mathrm{Br}_{2}\right]$ is shown in Figure 4. It consists of a strong singlet at 21 p.p.m. (relative to $85 \% \mathrm{H}_{3} \mathrm{PO}_{4}$ ) due to the phosphonium cation, and a weaker quartet centred at - 14 p.p.m. due to the co-ordinated $\mathrm{PPh}_{3}$ in the anion. As described previously, the quartet structure is due to spin-spin coupling of the phosphorus nucleus to the copper nucleus $\left({ }^{63} \mathrm{Cu},{ }^{65} \mathrm{Cu} ; I=\frac{3}{2}\right)$. The line spacings in the quartet are unequal, due to the presence of a nuclear quadrupole coupling interaction between the copper nucleus and its surroundings. ${ }^{3,4,15}$ For a spherically symmetric charge distribution about the copper nucleus, the nuclear quadrupole coupling constant would be zero, and the components of the quartet would be equally spaced. The marked asymmetry observed in the present case is thus a reflection of the electrical asymmetry about the copper nucleus which results from the relatively lowsymmetry trigonal-planar co-ordination environment.

In order to investigate possible relationships between the ${ }^{31} \mathrm{P}$ n.m.r. parameters and the co-ordination environment about the copper atom, the solid-state ${ }^{31} \mathrm{P}$ n.m.r. data obtained in the present study are compared with those for some related species in Table 4. The average chemical shift for $\left[\mathrm{Cu}\left(\mathrm{PPh}_{3}\right) \mathrm{Br}_{2}\right]^{-}$is more negative than those for the other bromocopper(I) complexes listed in Table 4. Since the last two compounds in this table also contain trigonal $\left(\mathrm{PPh}_{3}\right) \mathrm{CuBr}_{2}$ units, it appears that the chemical shift is not a good indicator of the co-ordination environment. The average line spacing $\left\langle\Delta v_{i}\right\rangle$ in the quartets increases with decreasing number of co-ordinated $\mathrm{PPh}_{3}$ ligands and is usually found in the range $0.9-1.0 \mathrm{kHz}$ for $\mathrm{Cu}\left(\mathrm{PPh}_{3}\right)_{3}$ compounds, $1.2-1.3 \mathrm{kHz}$ for $\mathrm{Cu}\left(\mathrm{PPh}_{3}\right)_{2}$ compounds, and 1.6 $1.8 \mathrm{kHz}$ for $\mathrm{Cu}\left(\mathrm{PPh}_{3}\right)$ compounds. This trend presumably reflects the decrease in $\mathrm{Cu}-\mathrm{P}$ bond lengths with decreasing number of co-ordinated ligands and a correspondingly greater degree of copper $4 s$-orbital participation in the $\mathrm{Cu}-\mathrm{P}$ bonding. It is also notable that the asymmetry, $\Delta v_{i j}$, in the quartet splittings is approximately the same for the two trigonal mononuclear complexes $\left[\mathrm{Cu}\left(\mathrm{PPh}_{3}\right)_{2} \mathrm{Br}\right]$ and $\left[\mathrm{Cu}\left(\mathrm{PPh}_{3}\right) \mathrm{Br}_{2}\right]^{-}$, but is much smaller for the tetrahedral mononuclear complex. This is in agreement with the expectation that the copper quadrupole coupling constant will be smaller for the tetrahedral than for the trigonal environment, as has been observed in related complexes by direct measurement of the nuclear 
Table 4. C.p.m.d.s. solid-state ${ }^{31} \mathrm{P}$ n.m.r. parameters for some bromocopper(1) complexes ${ }^{a}$

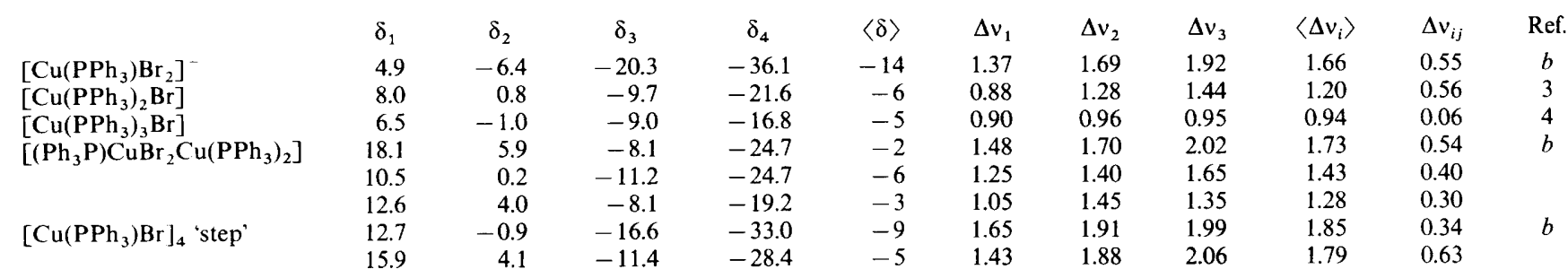

${ }^{a} \delta_{i}$ are the chemical shifts $\left( \pm 0.5\right.$ p.p.m.) with respect to $85 \% \mathrm{H}_{3} \mathrm{PO}_{4}\left(\delta\right.$ for solid $\mathrm{PPh}_{3}=-9.9$ p.p.m.); $\langle\delta\rangle$ is the average chemical shift for each quartet; $\Delta v_{i}$ is the splitting in $\mathrm{kHz}( \pm 0.03)$ between each of the four peaks of the quartet; $\left\langle\Delta v_{i}\right\rangle$ is the average of the $\Delta v_{i}$ for each quartet; $\Delta v_{i j}=\Delta v_{i}$ (max.) $-\Delta v_{i}$ (min.) is the asymmetry parameter of the quartet. ${ }^{b}$ This work.

quadrupole transition frequencies. ${ }^{16,17}$ The mean line spacing $\left\langle\Delta v_{i}\right\rangle$ and the quartet asymmetry parameters $\Delta v_{i j}$ for the unsolvated dinuclear and the tetranuclear aggregated complexes $\left[\left(\mathrm{Ph}_{3} \mathrm{P}\right) \mathrm{CuBr}{ }_{2} \mathrm{Cu}\left(\mathrm{PPh}_{3}\right)_{2}\right]$ and 'step' $\left[\mathrm{Cu}\left(\mathrm{PPh}_{3}\right) \mathrm{Br}\right]_{4}$ in Table 4 , both of which contain trigonally and tetrahedrally coordinated copper atoms, also reflect the difference between the two kinds of co-ordination environment, although for the dinuclear complex, overlapping bands from the three quartets makes accurate determination of the peak positions difficult. Copper nuclear quadrupole resonance frequencies have been measured for the trigonal and tetrahedral sites in $\left[\left(\mathrm{Ph}_{3} \mathrm{P}\right)\right.$ $\left.\mathrm{CuBr}{ }_{2} \mathrm{Cu}\left(\mathrm{PPh}_{3}\right)_{2}\right]$, and these are in this ratio $2: 1 .^{16,17}$ This suggests that the copper nuclear quadrupole coupling constants are in approximately the same ratio. The quartet at -2 p.p.m. in the solid-state ${ }^{31} \mathrm{P}$ n.m.r. spectrum of this complex has $\Delta v_{i j}=$ $0.54 \mathrm{kHz}$, which is almost the same as the values for the two trigonally co-ordinated mononuclear complexes $\left[\mathrm{Cu}\left(\mathrm{PPh}_{3}\right)_{2} \mathrm{Br}\right]$ and $\left[\mathrm{Cu}\left(\mathrm{PPh}_{3}\right) \mathrm{Br}_{2}\right]^{-}$. The $\left\langle\Delta v_{i}\right\rangle$ of $1.73 \mathrm{kHz}$ is in the range expected for the $\mathrm{Cu}\left(\mathrm{PPh}_{3}\right)$ fragment and this quartet is thus assigned to the phosphorus atom bound to the trigonal copper site in the complex. The other two quartets are assigned to the two phosphorus atoms co-ordinated to the tetrahedral copper site on the basis of the smaller values of $\left\langle\Delta v_{i}\right\rangle$ and $\Delta v_{i j}$. The $\Delta v_{i j}$ values are, however, larger than that for the phosphorus atoms in the tetrahedrally co-ordinated mononuclear complex $\left[\mathrm{Cu}\left(\mathrm{PPh}_{3}\right)_{3} \mathrm{Br}\right]$. This suggests that the copper quadrupole coupling constants are quite different for the two different co-ordination environments $\left(\mathrm{P}_{2} \mathrm{CuBr}_{2}\right.$ and $\mathrm{P}_{3} \mathrm{CuBr}$ ) involved, despite the fact that the co-ordination number is four in both cases. In the 'step' form of $\left[\mathrm{Cu}\left(\mathrm{PPh}_{3}\right) \mathrm{Br}\right]_{4}$ the nuclear quadrupole resonance frequency of the trigonally co-ordinated copper atom has been measured, ${ }^{16}$ and is almost identical to that of the trigonal copper atom in $\left[\left(\mathrm{Ph}_{3} \mathrm{P}\right) \mathrm{CuBr}{ }_{2} \mathrm{Cu}\left(\mathrm{PPh}_{3}\right)_{2}\right]$ and one quartet for the unsolvated 'step' $\left[\mathrm{Cu}\left(\mathrm{PPh}_{3}\right) \mathrm{Br}\right]_{4}$ has a $\Delta v_{i j}$ which is comparable in magnitude to the values for the trigonal sites in the other compounds in Table 4 and the other to the tetrahedral $\mathrm{PCuBr}_{3}$ site.

While these results provide a consistent relationship between the structural parmeters of the $\left[\mathrm{Cu}\left(\mathrm{PPh}_{3}\right)_{m} \mathrm{X}\right]_{n}$ system and the n.m.r. parameters $\Delta v_{i}$ and $\Delta v_{i j}$, as a cautionary note we report that for the spectra of solvated or partially solvated forms of the 'step' $\left[\mathrm{Cu}\left(\mathrm{PPh}_{3}\right) \mathrm{Br}\right]_{4}{ }^{18}$ the differences in these parameters for the trigonal and tetrahedral copper sites is much less marked, and more work is still required to elucidate the origins of these effects.

\section{Conclusions}

The present study establishes the existence of the first anionic mixed-ligand complexes of copper(I) with halide and triphenyl- phosphine. The isolation of $\left[\mathrm{Cu}\left(\mathrm{PPh}_{3}\right) \mathrm{Br}_{2}\right]^{-}$in the presence of excess of $\mathrm{PPh}_{3}$ suggests that $\mathrm{CuBr}_{2}{ }^{-}$is only able to accommodate one $\mathrm{PPh}_{3}$ molecule in its co-ordination sphere. Trends in metal-ligand bond lengths, ${ }^{31} \mathrm{P}$ n.m.r. line spacings, and bond-stretching force constants between this and related species can be understood on the basis of a greater $\sigma$-donor capacity for $\mathrm{PPh}_{3}$ relative to $\mathrm{Br}^{-}$, and establish a close similarity between the $\left(\mathrm{PPh}_{3}\right) \mathrm{CuBr}_{2}$ unit in various structures, irrespective of whether the $\mathrm{Br}$ atoms are terminal or bridging.

\section{Acknowledgements}

We thank Dr. A. Camus for suggesting the investigation of the type of complex reported here, and Mrs. Catherine Hobbis for assistance with the preparative work. The Bruker CXP-300 spectrometer is operated by the Brisbane N.M.R. Centre and we thank the Centre for making instrument time available. We thank Mr. David Tucker for recording the solid-state ${ }^{31} \mathrm{P}$ spectra and Ms. Candiera Albert for assistance in the preparation of some of the neutral complexes used. We are grateful to the New Zealand Universities Grants Committee and the Australian Research Grants Scheme for financial assistance.

\section{References}

1 G. A. Bowmaker, Adv. Spectrosc., 1987, 14, 1

2 G. A. Bowmaker, G. R. Clark, D. A. Rogers, A. Camus, and N. Marsich, J. Chem. Soc., Dalton Trans., 1984, 37.

3 G. A. Bowmaker, J. C. Dyason, P. C. Healy, L. M. Engelhardt, C. Pakawatchai, and A. H. White, J. Chem. Soc., Dalton Trans., 1987, 1089.

4 P. F. Barron, J. C. Dyason, P. C. Healy, L. M. Engelhardt, C. Pakawatchai, V. A. Patrick, and A. H. White, J. Chem. Soc., Dalton Trans., 1987, 1099.

5 J. C. Dyason, L. M. Engelhardt, C. Pakawatchai, P. C. Healy, and A. H. White, Aust. J. Chem., 1985, 38, 1243.

6 'International Tables for $X$-Ray Crystallography,' eds. J. A. Ibers and W. C. Hamilton, Kynoch Press, Birmingham, 1974, vol. 4.

7 S. R. Hall, The XTAL User Manual, Technical Report of the Computer Science Centre, University of Maryland, U.S.A., 1983.

8 S. Anderson and S. Jagner, Acta Chem. Scand., Ser. A, 1985, 39, 297, 515,$577 ; 1986,40,210 ;$ M. Asplund, S. Jagner, and M. Nilsson, ibid., 1983, 37, 57.

9 R. P. Shibaeva, V. F. Kaminskii, E. B. Yagubskii, and L. A. Kushch, Sov. Phys. Crystallogr., 1983, 28, 48.

10 J. C. Dyason, L. M. Engelhardt, P. C. Healy, H. L. Klich, and A. H. White, Aust. J. Chem., 1986, 39, 2003.

11 G. A. Bowmaker and D. A. Rogers, J. Chem. Soc., Dalton Trans., 1984, 1249.

12 G. A. Bowmaker and P. C. Healy, Spectrochim. Acta, Part A, 1988, 44, 115. 
13 G. A. Bowmaker, L. D. Brockliss, and R. Whiting, Aust. J. Chem., 1973, 26, 29.

14 B-K. Teo and D. M. Barnes, Inorg. Nucl. Chem. Lett., 1973, 12, 681. 15 E. M. Menger and W. S. Veeman, J. Magn. Reson., 1982, 46, 257.

16 T. Okuda, M. Hiura, K. Yamada, and H. Negita, Chem. Lett., 1977, 367.
17 H. Negita, M. Hiura, K. Yamada, and T. Okuda, J. Mol. Struct., 1980, 58, 205.

18 P. F. Barron, J. C. Dyason, L. M. Engelhardt, P. C. Healy, and A. H. White, Inorg. Chem., 1984, 23, 3766.

Received 22nd February 1988; Paper 8/00687C 